Martin Wallraff

Kodex und Kanon 


\author{
Akademieunternehmen \\ „Die alexandrinische und antiochenische \\ Bibelexegese in der Spätantike - \\ griechische christliche Schriftsteller" \\ der Berlin-Brandenburgischen Akademie der \\ Wissenschaften
}

\title{
Hans-Lietzmann-Vorlesungen
}

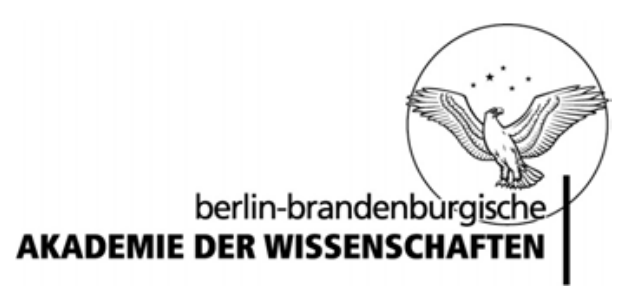

Herausgegeben von
Christoph Markschies

Heft 12

De Gruyter 


\section{Martin Wallraff}

\section{Kodex und Kanon}

Das Buch im frühen Christentum 


\section{ISBN 978-3-11-030712-2 \\ e-ISBN 978-3-11-030718-4 \\ ISSN 1861-6011}

\section{Library of Congress Cataloging-in-Publication Data}

A CIP catalog record for this book has been applied for at the Library of Congress.

\section{Bibliografische Information der Deutschen Nationalbibliothek}

Die Deutsche Nationalbibliothek verzeichnet diese Publikation in der Deutschen Nationalbibliografie; detaillierte bibliografische Daten sind im Internet über http://dnb.dnb.de abrufbar.

(C) 2013 Walter de Gruyter GmbH, Berlin/Boston

Druck: Hubert \& Co. GmbH \& Co. KG, Göttingen

$\infty$ Gedruckt auf säurefreiem Papier

Printed in Germany

www.degruyter.com 